\title{
The Effect of COVID-19 on Credit and Capital Risk of State-Owned Bank in Indonesia: A System Dynamics Model
}

\author{
TAufiq Hidayat ${ }^{1}$, Dian Masyita ${ }^{2}$, SulaEman RAhMan NidaR $^{3}$, ERIE FEbrian $^{4}$, \\ FAUZAN AHMAD 5 \\ ${ }^{1}$ STIE Indonesia Banking School Jakarta, INDONESIA \\ ${ }^{2,3,4}$ Faculty of Economic and Business, Padjadjaran University Bandung, INDONESIA \\ ${ }^{5}$ System Dynamics Bandung Bootcamp, INDONESIA
}

\begin{abstract}
The global COVID-19 pandemic has greatly affected people, especially in the economic and banking sectors. The Indonesian Financial Services Authority (Otoritas Jasa Keuangan, OJK) issued a credit restructuring policy, effective from March 2020 to March 2022, to reduce credit and bank capital risk. This study proposes the bank risk scenario after the credit restructuring policy of the OJK moratorium in March 2022 and proposes the internal bank policy simulation to mitigate credit and capital risks in terms of Non-Performing Loan (NPL) and Capital Adequacy Ratio (CAR). The difficulty of this study is how to develop the risk scenario and to simulate the bank risk mitigation policy after the policy moratorium, while the COVID-19 pandemic is still ongoing and the economy is not yet normal.

To that purpose, this study uses a system dynamics methodology with Powersim Studio $10^{\circ}$ software that is able to make scenarios on the level of credit risk (NPL) and bank capital (CAR) and able to simulate internal bank policy to overcome the risk by considering the environmental and policy changes. Based on the policy simulation, it is recommended that bank can implement the restructuring policy to control the credit risk and strengthening the NPL monitoring activity in order to manage and decrease the loan impairment expenses. To increase CAR, the result shows that the combined policy consists of the NPL monitoring program, the interest rate and the operating cost management program
\end{abstract}

is able to produce a significant increase in bank's capital (CAR) The orioinal contribution of this study
is to provide new model of credit and capital risk scenario and fisk miftgation stmutation during COVID-19 pandemic. The advantage of this study is that the model can be tested and implemented to other banks.

Keywords: - Covid-19, Credit Risk, Capital Risk, System Dynamics, Credit Restructuring Policy, Simulation, Banking

Received: January 29, 2021. Revised: July 2, 2021. Accepted: July 12, 2021. Published: July 19, 2021.

\section{Introduction}

The COVID-19 pandemic has led to the closure of several sectors and worsening the economic crisis [1]. This pandemic has also interfered with education and mental health of the people [24], [48], a different situation from the previous global financial crisis [25]. The tourism, aviation, and other service industries have stopped operating, leading to unemployment. The impact of the COVID-19 pandemic on economic destruction was illustrated by the decline in several macroeconomic indicators, including production aggregate, supply, trade flows, savings, investment, and employment [11]. Furthermore, the pandemic affected the bank operations.

Banks could not easily generate funding from the communities and businesses during the pandemic because economic deterioration hampered public life. Consequently, there were difficulties in increasing banks' lending because the COVID-19 affected the borrowers' capability to repay the loans. This implies that the volume of unpaid credit would increase in case the pandemic prolongs. This would reduce bank liquidity, increase the Non-Performing Loan (NPL) and loan impairment expenses, and decrease bank income and capital [9], [18]. 
Studies on the pandemic's impact on banking show an increase in NPL and a decline in bank CAR [11], [19].

The COVID-19 pandemic affected Indonesian banking sector, leading to increased NPL and low CAR. For this reason, OJK issued a policy in March 2020 Number 11/2020 extended to Number 48/2020. This policy made it easier for banks to restructure their outstanding credit. As a result, the bank's NPL level has been lowered, and the CAR ratio maintained. However, there are uncertainty concerns in the banking industry that NPL would increase and CAR decrease in case the COVID-19 pandemic prolongs since the policy is effective only until March 2022. Therefore, this study proposes the bank risk scenario after the OJK loan restructuring policy moratorium in March 2022. Additionally, it proposes the internal bank policy simulation to mitigate the effect of credit (NPL) and insolvency (CAR) risks. The system dynamics methodology was used to generate scenarios and internal bank policy simulations on credit risk and banking capital after the OJK policy moratorium. This methodology overcomes the weakness of historical data-based statistical modeling to simulate the bank NPL and CAR risks during the COVID-19 pandemic [8], [47].

This paper simulates the credit and capital risks of BNI Bank, one of the state-owned banks in Indonesia affected by the pandemic. In 2020, the NPL ratio of BNI increased by $86.96 \%$, return on assets (ROA) decreased by $79.17 \%$, and the capital adequacy ratio (CAR) fell by $12.36 \%$. Furthermore, the total outstanding loans were IDR 586 trillion in 2020. These included non-performing loans of IDR 24.6 trillion (4.2\%) and loans restructured due to the pandemic, amounting to IDR 148.94 trillion $(25.41 \%)$. Restructured loans are the NPL treated as performing loans based on OJK policies. Based on the analysis report of the Indonesia banking industry in 2020, there would be a potential NPL of $50 \%$ of the outstanding restructured loans when the OJK policy is a moratorium on March 2022. Regarding this prediction, BNI's NPL and CAR ratios would be at a high risk and increasing the bankruptcy risk. All those are the background for this study, that used the words of loan and credit as well as equity and capital interchangeably.

\section{Literature Review}

NPL is the loan risk arising when the borrower does not pay loan obligations according to the schedule. When the loan is non-performing, the bank is delayed in cash inflow, resulting in increased loan impairment expenses. Furthermore, the constrained cash inflow reduces the available funds for new loan growth, while the increase in impairment cost decreases the bank's capital. Consequently, reduced capital increases the risk of bank bankruptcy [30], [37], [39].

Previous studies implemented parametric statistical models with accounting ratios and market data to predict the credit and capital risks [5], [31], [29], [16], [15]. Some studies showed that during the COVID-19 pandemic, loan quality declined, NPLs increased, bank capital deteriorated and the operations of large banks were affected [2], [18, [19], [11], [25], [26]. Similarly, the COVID-19 pandemic affected the performance of the profit of banks in Indonesia [35]. Those studies indicate that the NPL and CAR ratios are good predictors of a bank's bankruptcy risk [22], [12], [14]. However, the studies did not provide information on scenarios of NPL and CAR risk levels during the Covid-19 pandemic and policy simulations to overcome them. There are some solutions to respond the condition, including the recommendation that banks increase the credit lending to the businesses that unaffected by the COVID-19 pandemic, increasing the effectiveness of loan monitoring, implementing the operating cost efficiency and managing the interest rates [43], [23]. In order to provide the risk scenario of the bank, some studies used the system dynamics approach by analyzing the loan, capital, and bank bankruptcy risks using system dynamics approach [28], [33], [34], [4], [20], [47], [21]. System dynamics are also useful in predicting bank risk scenarios, modeling mitigation policies and can provide some early information to mitigate the risks [20], [32]. Studies with system dynamics in banking sectors were using the data of the bank balance sheet and a profit and loss statement [6], [20], [33].

System dynamics modeling is a futureoriented simulation that helps management to formulate the best policies [46], [10], [1], [3]. Simulation is a model or replication that 
emulates the operation of a real-world system over time. It uses computer software models to understand better the interactions between the many structures within the system [38].

The tools used to describe the structure and interactions between structures in system dynamics modeling are Causal Loop Diagrams (CLD) and Stock Flow Diagrams (SFD) [27]. CLD is a visual map to determine the relationship of feedback and cause-effect between interacting variables in the system. Also, it serves as a hypothesis for the system's behavior being modeled [41], [36]. Stock \& Flow Diagram (SFD) is a CLD formulated in the relationship diagram between variables in the stock (level) and flow (rate). Stock is the variable indicating the accumulation of change, and flow shows the level of change [17], [13].

The scenarios produced by the system dynamics contained of some parameters of NPL and CAR level, that should be compared with the respective bank regulation. The maximum standard of loan risk measured by the NPL ratio is $5 \%$ of the total loan, while the standard of CAR is at least $10 \%$. An NPL ratio is greater than 5\%, and CAR less than $10 \%$ increase the risk of bank bankruptcy [9].

\section{Research Methodology}

This research used the system dynamics methodology to simulate the increase in loan and capital risks before and after the OJK loan restructuring policy for banks affected by the pandemic. The model is prepared based on some accounts in the bank's balance sheet and profit and loss statement [6], [20], [33]. The causal loop diagram shows the relationship between variables that affected the loan and capital behavior in the modeling. Furthermore, the stock-flow diagram shows the loan and equity (capital) quantitative transactions in the monetary unit.

\subsection{Modeling Causal Loop Diagram of Credit and Capital Risk}

This research analyzed credit risk and capital risk. Figure 1 shows the causal loop diagram on the effect of the COVID-19 pandemic on credit and capital risk. Also, the figure shows the cash flow from TPF (Third Party Funds) to be the liquid asset to increase the availability of funds for lending. Loan instalments that consist of the principal and interest payment will increase liquid assets and bank capital. When a loan has a problem with its repayment, it is classified as a non-performing loan (NPL). In this case, bank should advise borrowers and restructure the loan to be performing. However, when the NPL becomes worst, it needs to be written off by the bank.

Figure 1: Causal Loop Diagram of Loan Risk and Capital Risk

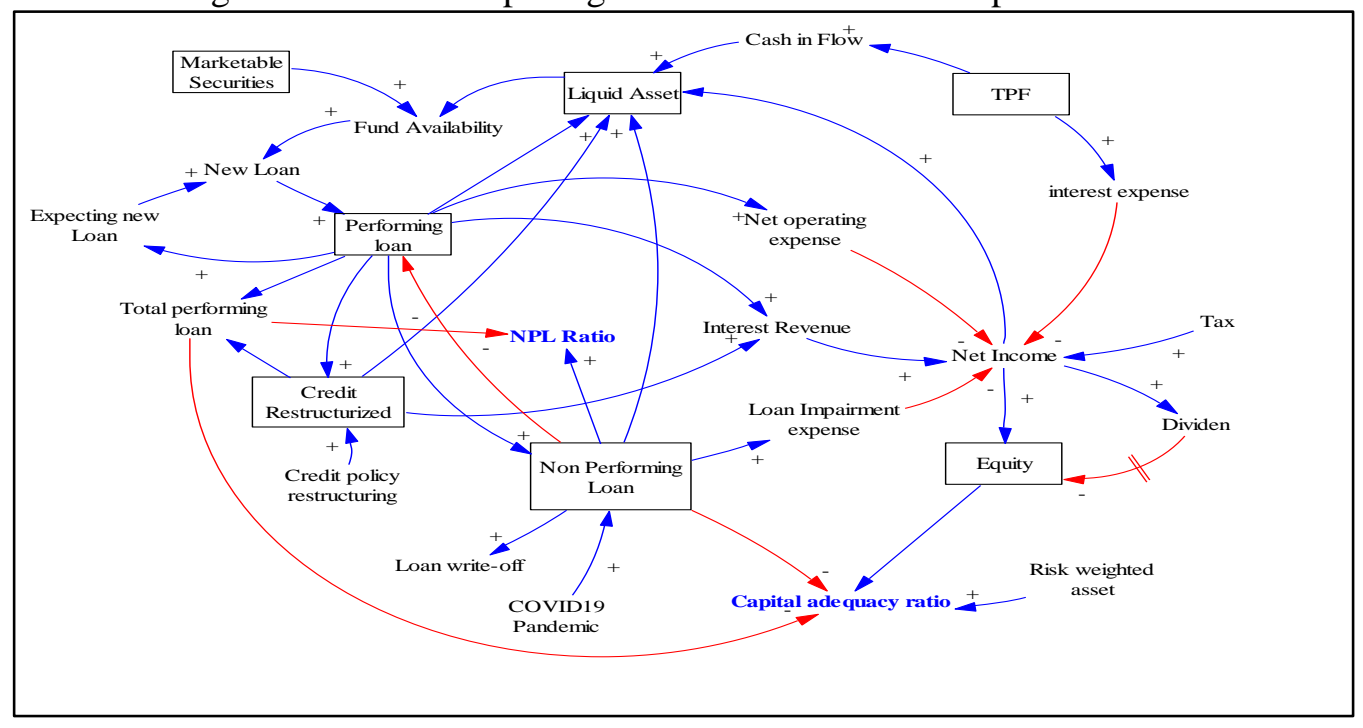

Credit risk arises due to an increase in NPL and is measured by the NPL ratio to total loan. A high NPL requires bank to incur loan impairment expenses, which reduce their net income. To counter this, bank must establish a higher allowance for impairment losses to reduce the minimum capital adequacy ratio (CAR). This is the risk of bank capital, which 
leads to bankruptcy in case it significantly declines.

The COVID-19 pandemic has caused an abnormal increase in loan risk. As a result, OJK issued a loan restructuring policy to overcome this risk. Therefore, loans with the potential to be NPL are restructured and performed to reduce impairment expenses and maintain the CAR ratio. Table 1 shows the relationship between NPL, CAR, the COVID-19 pandemic, and the Credit Restructuring Policy.

Table 1: Predicted Impact of Variables on CAR and NPL

\begin{tabular}{|c|c|c|}
\hline Variable & CAR & NPL \\
\hline COVID19 Pandemic & - & + \\
\hline Credit Restructuring Policy & + & - \\
\hline
\end{tabular}

\subsection{Modeling Stock Flow Diagram of Credit and Capital Risk}

The next modeling step translates the causal loop diagram of credit and capital risk into stock and flow (rate) categories of loan mechanism, as shown in Figure 2. The stock category comprises the variables with accumulation or storage characteristics capable of determining the balance at any time. All the accounts in the balance sheet are stocks that consisting of liquid assets, loans, third party fund (TPF) and equity. The liquid asset and loan are the bank's investment portfolio that generate interest and fee-based income at the expense of a certain risk.

Figure 2: Stock Flow Diagram of Loan

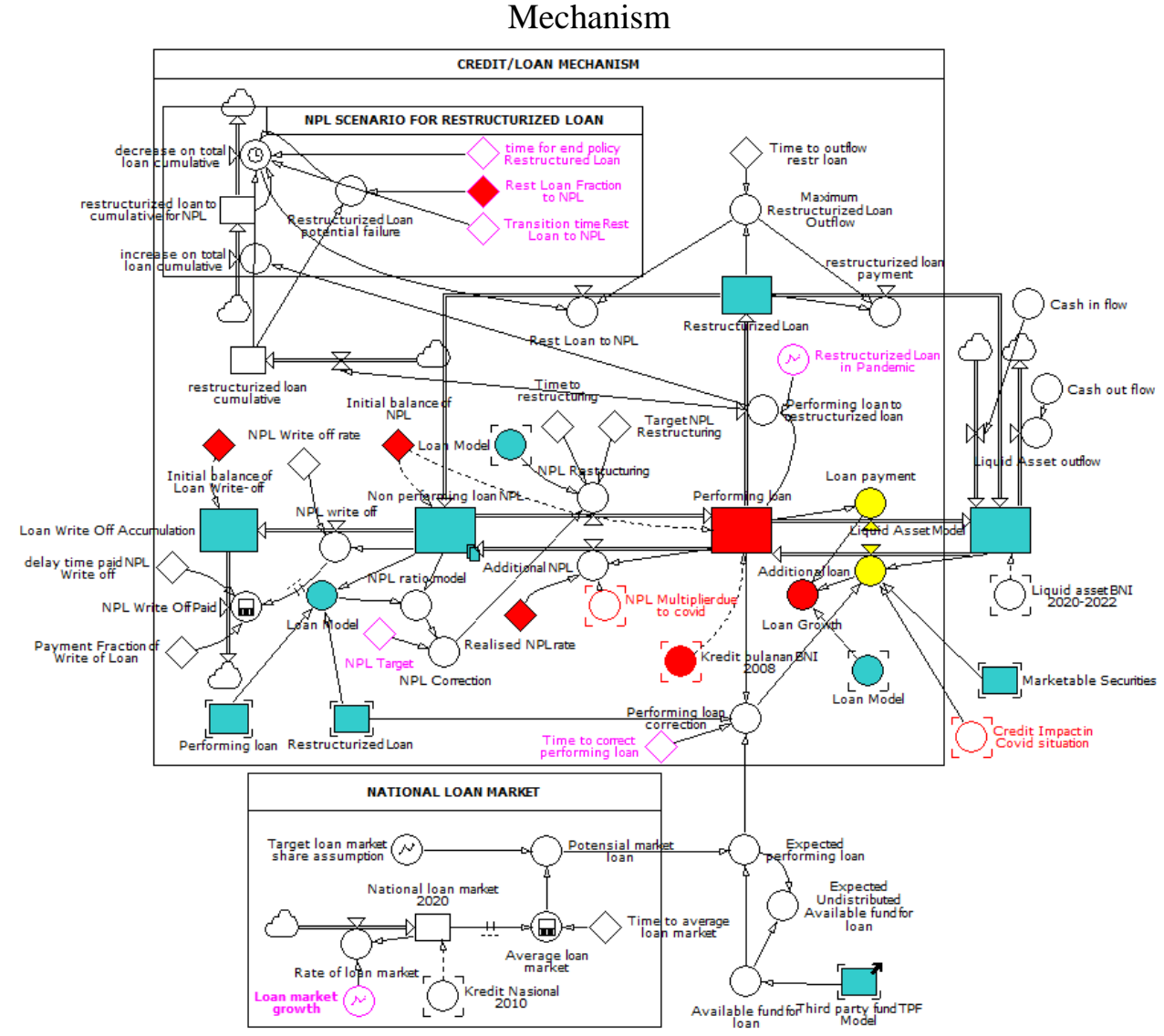

The loan investment structure is classified into the following four stocks to control loan risk and return:

- Performing loans paid installment on time and regularly. An additional loan is added to this stock and deducted based on time and regular payment.

- Restructured Loan is a potential NPL classified as a performing loan due to the
OJK policy to lighten the borrower's burden during the pandemic.

- Non-Performing Loan (NPL) is loan that delayed in payment for more than 90 days. The NPL inflow is determined by a rate calculated from historical data assumed in a normal condition and affected by COVID19. It represents the behavioral change in the borrower's ability to pay. 
- NPL Write off Accumulation is associated with non-performing loans that are less likely to be repaid. Bank issue a policy to write off these loans, which are booked as NPL Write Off Accumulation. Therefore, they are not included in bank accounts but are charged to the borrower.

- Performing loans is the main source of interest income and liquidity. During normal business, part of it becomes NPL. Therefore, bank needs to allocate loan impairment expenses.

Figure 3 shows the COVID-19 impact on loan mechanism in NPL rate and loan activity. The figure shows the COVID-19 time hit $\left(3^{\text {rd }}\right.$ month of 2020) and how long NPL rate and credit risk are affected by the pandemic. Also, it shows the adjusting starting time for Bank, with borrowers starting from when the pandemic was discovered, and adjusting time for Bank borrowers based on when the pandemic would end.

Figure 3: Diagram of COVID-19 Impact on Loan

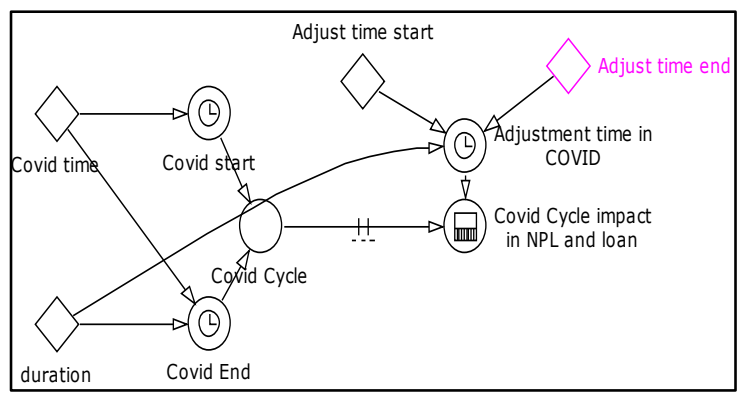

The performing loan is restructured to change its tenor and interest to comply with OJK regulation as a countercyclical of COVID19 pandemic. Based on the regulation, the loan is restructured extraordinarily. Loan restructured increased loan quality without additional impairment expenses. The model shows that the bank's compliance with OJK regulation affects performing loan, NPL, and write-off accumulation. Additionally, the model illustrates the behavior of loans, NPL, and equity during the pandemic.

Figure 4 shows the simulation of COVID-19 period and its impact to NPL and loan mechanism. A value of 1.0 indicates that the pandemic is still active and reduces the loan activities, while 0.0 means they are at a normal level. Also, the graph shows that loan activities may return to normal after the 36th month (on December 2022).

Figure 4 Simulation of COVID-19 Impact on Loan

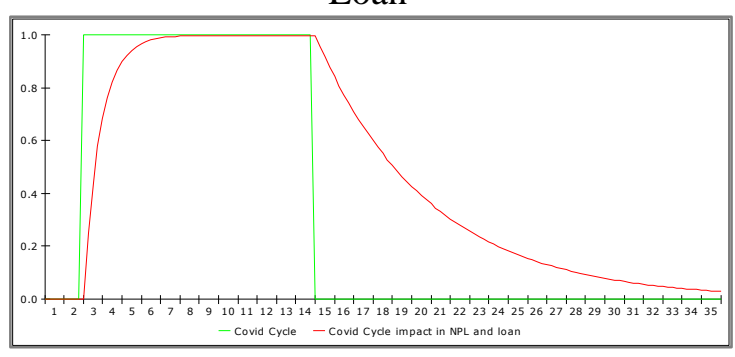

Figure 5 shows that the stock-flow diagram of bank equity. The equity increases through profit after tax and decreases by the payment of dividends. Profit after tax is calculated by subtracting expenses from the income. The income is sourced from the interest and operating income, while expenses consist of interest, operating and loan impairment expenses. During the economic crisis and COVID-19 pandemic, loan impairment expense increases significantly, creating bank losses and reducing equity. Consequently, reduced capital increases the risk of bank bankruptcy.

Figure 5: Stock Flow Diagram of Bank Equity (Capital)

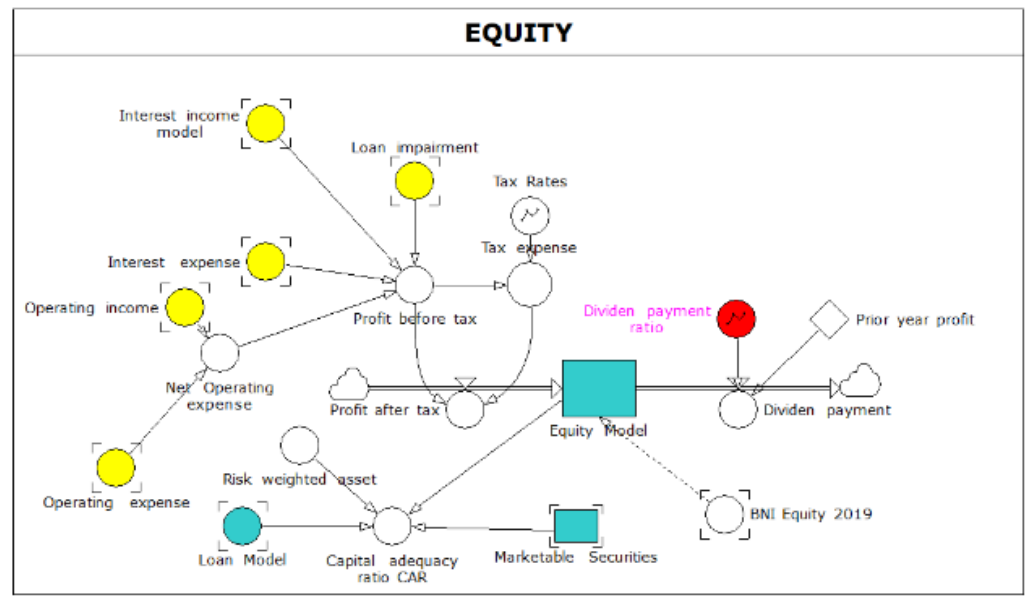




\section{Model Configuration and Test}

The model configuration comprises the setup process, including initial parameters values, time set-up, and simulation time. The Initial Values and Constant Values of the Baseline Model are shown in the Appendix of this paper. The model is set to run in a 0.25 -month time step, with the simulation time of the $1^{\text {st }}$ month starting on 1 January 2020 and ending on the $36^{\text {th }}$ month, which is on 31 December 2022. Historical data is available from 1 January 2020 $\left(1^{\text {st }}\right.$ month $)$ until 31 December $2020\left(12^{\text {th }}\right.$ month).

The model was validated and used to compare the simulation and historical data to build the model confidence [40]. Several results of comparison between model simulation and historical data are shown in Figures 6 and 7. The model comparison has a similar trajectory with the historical data from the $1^{\text {st }}$ to the $12^{\text {th }}$ month.

Figure 6: Historical and Simulation Data of Loan

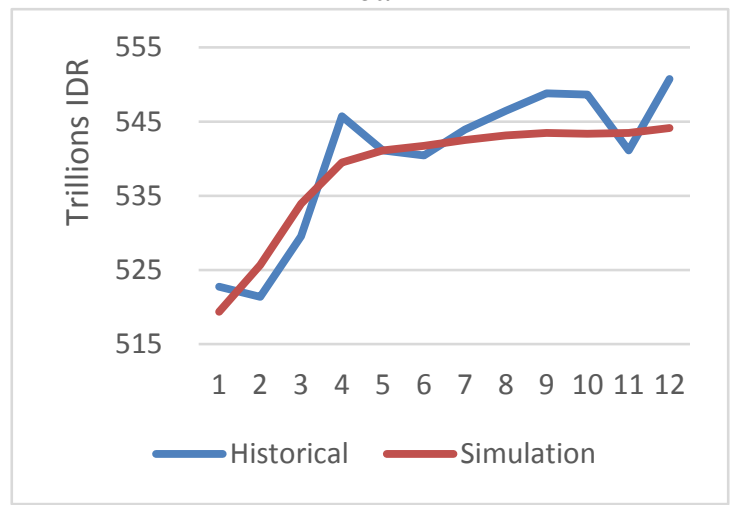

Figure 7: Historical and Simulation Data of Capital

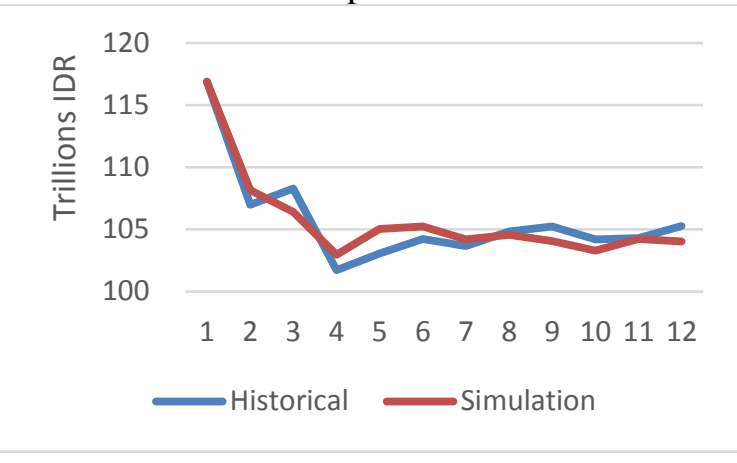

To test the ability of the model to represent the data on the system created, this study used the Behavior Reproduction Test [41]. It uses several parameters to ensure the system is functioning properly, including $\mathrm{R}^{2}$, Root Mean Square Percentage Error (RMSPE), Mean Square Error (MSE), and Theil's Inequality Statistic, as shown in Table 2.

$\mathrm{R}^{2}$ is the coefficient of determination or the fraction of the variance in the data determined or explained by the model. This parameter includes $r$ for the correlation coefficient between the model and the data series. In this case, $\mathrm{R}^{2}=1$ when the model shows actual data. Theil's Inequality Statistics decomposes MSE into bias $\left(\mathrm{U}^{\mathrm{M}}\right)$, unequal variation $\left(\mathrm{U}^{\mathrm{S}}\right)$, and unequal covariation $\left(\mathrm{U}^{\mathrm{C}}\right)$, in which $\mathrm{U}^{\mathrm{M}}+\mathrm{U}^{\mathrm{S}}+$ $\mathrm{U}^{\mathrm{C}}=1$. To check the capability of the model, the test is carried out on the Loan by comparing the historical data in 2020 and the simulation.

Table 2: Model Fits Historical Data (error analysis)

\begin{tabular}{|l|c|c|c|c|c|c|}
\hline Variable & RMSPE & MSE & $U^{m}$ & $U^{S}$ & $U^{C}$ & $R^{2}$ \\
\hline Loan & 0.008902259 & $7.92502 \mathrm{E}-05$ & 0.00265 & 0.02297 & 0.97431 & 0.972 \\
\hline Capital & 0.014364056 & 0.000206326 & 0.07996 & 0.02683 & 0.89105 & 0.9754 \\
\hline
\end{tabular}

The $\mathrm{R}^{2}$ value in the simulation data is 0.97 or close to 1 , which is relatively high. This means the simulation results can explain the dynamics of the historical-comparative data. However, there is a relatively small difference in each component of Theil Statistics.
Furthermore, the $\mathrm{U}^{\mathrm{M}}$ value of 0.00265 or close to 0 indicates a relatively small bias or deviation between the two data. The $\mathrm{U}^{\mathrm{S}}$ and $\mathrm{U}^{\mathrm{C}}$ values are 0.02297 and 0.97431 (close to 1), respectively. The $\mathrm{U}^{\mathrm{C}}$ value shows that most errors are concentrated in the covariance inequality. In 
comparison, $\mathrm{U}^{\mathrm{M}}$ and $\mathrm{U}^{\mathrm{S}}$ are small, with the same mean and variance but a time shift of the two data. The model allows unsystematic error qualification, meaning it functioned properly [40].

The $\mathrm{R}^{2}$ value in the simulation for the equity (capital) parameter is 0.9754 (close to 1 ), which is relatively high. This means that the simulation results can explain the dynamics of historical data. Moreover, the $\mathrm{U}^{\mathrm{M}}$ value is 0.07996 , the $\mathrm{U}^{\mathrm{S}}$ is 0.02683 , and the $\mathrm{U}^{\mathrm{C}}$ is 0.89105 . Therefore, the $\mathrm{U}^{\mathrm{M}}, \mathrm{U}^{\mathrm{S}}$, and $\mathrm{U}^{\mathrm{C}}$ values show no relative bias or deviation. The model is categorized as unsystematic error, meaning it is useful in proposing policy simulations.

The RMSPE decomposition shows that the $\mathrm{U}^{\mathrm{C}}$ values are bigger in both cases, meaning that the model reasonably represents the data's mean and underlying trends. Also, the error is related to a difference from point-to-point estimation [41]. Previous studies showed that projections from the calibrated model are more trustworthy than forecasts from other methodologies [47].

A comparison was carried out between the historical and the simulation data. The results showed that the simulation perfectly mimicked historical data. Several differences occurred in the comparison due to the delay function in the model to replicate its behavior and averaging process and smooth cyclical pattern in the historical data.

\section{Model Simulation}

This study used simulation modeling with Powersim Studio 10@ software. The stages of the model included baseline, NPL, and CAR ratio simulation. Baseline simulation was conducted to generate NPL and capital risk indicators when the bank operates during the COVID-19 pandemic while the OJK loan restructuring policy is ongoing. This first simulation resulted in the Baseline Data. The second simulation was conducted to determine the level of NPL and CAR risks after the moratorium of the OJK loan restructuring policy. The third simulation is performed on the internal bank policies to mitigate the NPL and CAR risks after the moratorium.

\subsection{Baseline Data}

Baseline data refers to the banks' financial performance from the $1^{\text {st }}$ to the $36^{\text {th }}$ month, or the period between 1 January 2020 to 31 December 2022. The baseline data was compiled from historical data during 2020 and projections for 2021 and 2022 based on historical performance. Also, several assumptions were considered, such as TPF and loan growth, NPL ratio, and CAR projections. The baseline data provides some financial information of NPL and CAR levels in the COVID-19 pandemic under the OJK policy of loan restructuring. This information is a reference or comparison for simulating loan and capital risks after the OJK policy moratorium policy. Furthermore, it compares the simulations for internal bank policies after the policy moratorium.

Figure 8 shows baseline data for credit and TPF growth. The TPF is the main source of bank funding that grows with the assumption of $8-9 \%$ until the end of 2022. In the $6^{\text {th }}$ to $8^{\text {th }}$ periods, TPF experienced a significant increase compared to the previous period due to the additional Government deposits. This boosted credit growth and net bank income. In this case, by the end of 2022, the loan is estimated to grow to IDR 630.52 trillion or by $86 \%$ of the TPF. The loan consists of performing and restructuring loans, as well as NPLs.

Figure 8: Third-Party Fund and Loan Baseline

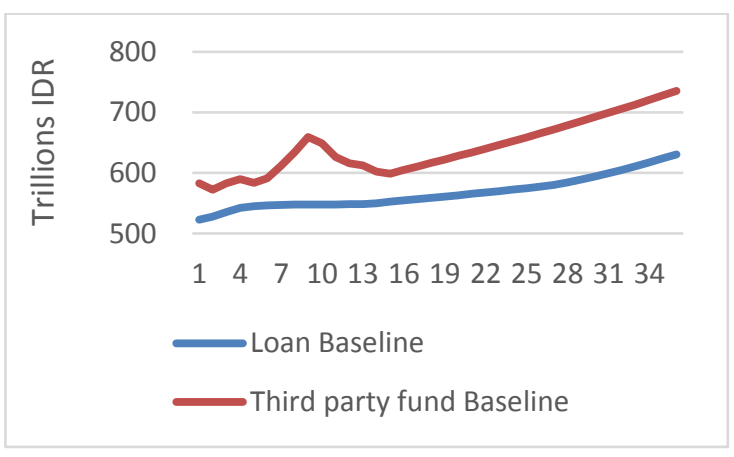

Figure 9 shows the NPL Ratio and CAR baseline of BNI Bank. There was an increase and significant decrease in NPL ratio and CAR in the 1st to 10th month period, respectively. Therefore, bank increase impairment expenses to anticipate an increase in NPL, though this decreases CAR. The NPL Ratio decreased after 
the 10th month because the bank applied the OJK credit restructuring policy. Bank should conduct simulations to anticipate the increase in NPL risk and a decrease in CAR when the OJK policy ends in March 2022. Additionally, they should simulate internal policies to minimize the decline in CAR.

Figure 9: NPL Ratio \& CAR Baseline

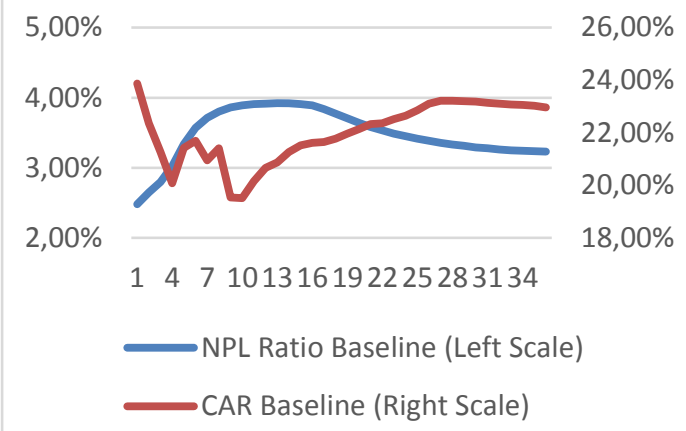

Bank increases allowance for impairment loss to anticipate the potential increase in credit risk during the pandemic. Figure 10 shows that the bank has an equity balance and allowance for impairment losses (accumulation of impairment expenses) of IDR 155.66 trillion and IDR 53.13 trillion, respectively. This is higher than the projected NPL balance of IDR 20.05 trillion, meaning that the bank is financially capable of anticipating the future increase in NPL risk.

Figure 10: Baseline Simulation for Equity, Allowance for Impairment Losses and NPL

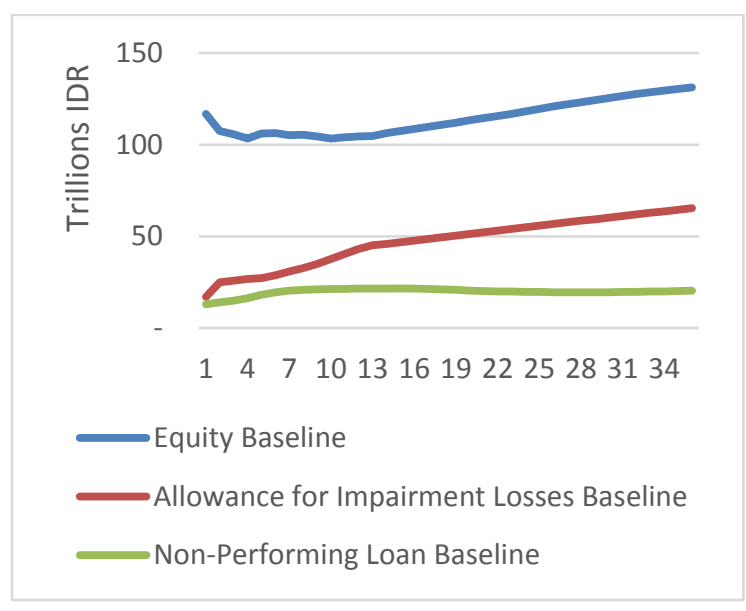

\subsection{Bank Risk Simulation on the Scenario of OJK Policy Moratorium}

Credit and capital risks are simulated with the scenario of discontinuing the OJK credit restructuring policy in March 2022. It is necessary to determine several new simulation parameters to project the conditions after the policy moratorium as shown in Figure 11. These parameters include: $50 \%$ of the restructured loan outstanding is considered NPL, the revocation of the OJK policy is in March 2022, and there is a 2-month lag time for loans to become NPLs.

Figure 11: Policy Structure of Restructured Loan

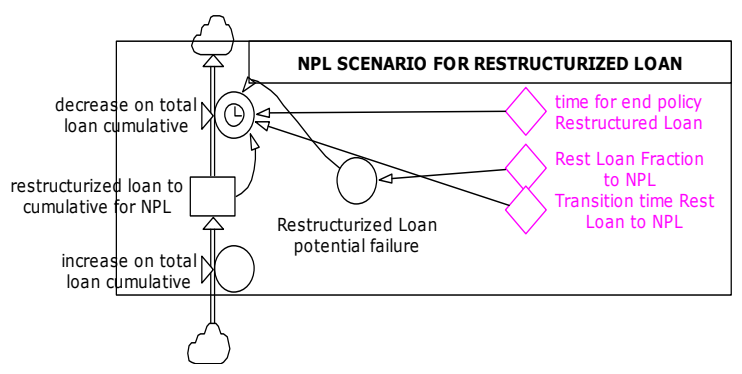

NPLs could rise in case the economy remains abnormal after the OJK policy moratorium in March 2022. It is estimated that around IDR 73.5 trillion, or $50 \%$ of the total outstanding restructured loans of IDR 147 trillion, would become NPLs. Based on the published bank financial statements, more than $50 \%$ of the restructured loans were distributed to the industrial, trade, hotel, and restaurant sectors. These sectors experienced a significant decrease in business performance during the COVID-19 pandemic. However, the outcome of this scenario may change in case credit is restructured effectively before the moratorium. Figure 12 shows that for 2-3 months after the moratorium, the NPL ratio increased from $3.33 \%$ to $11.16 \%$ in the $33^{\text {rd }}$ month and became relatively stable until December $2022\left(36^{\text {th }}\right.$ month). 
Figure 12: Scenario Simulation for NPL Ratio

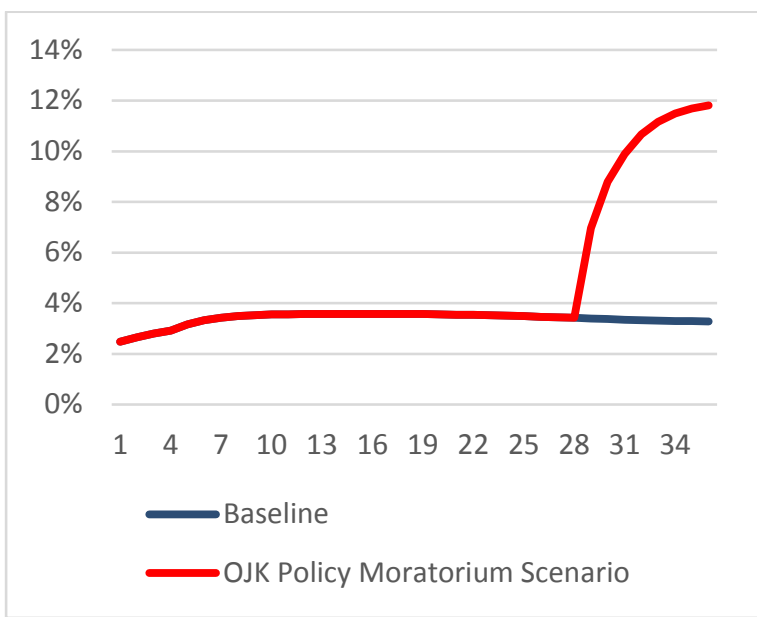

There is a potential for CAR to decrease, similar to the NPL risk simulation. However, the simulation results show that the decrease in CAR was not as high as the increase in the NPL ratio. The CAR baseline data was at $23.23 \%$ in the $28^{\text {th }}$ period, though it would decrease to $22.17 \%$ in the $36^{\text {th }}$ month after the moratorium as shown in Figure 13. This is because the bank has the allowance impairment losses at a sufficient level (Figure 10). During this period, the CAR level was still higher than BNI Bank's mandatory CAR at the minimum level of $9.95 \%$.
Figure 13: Scenario Simulation for CAR

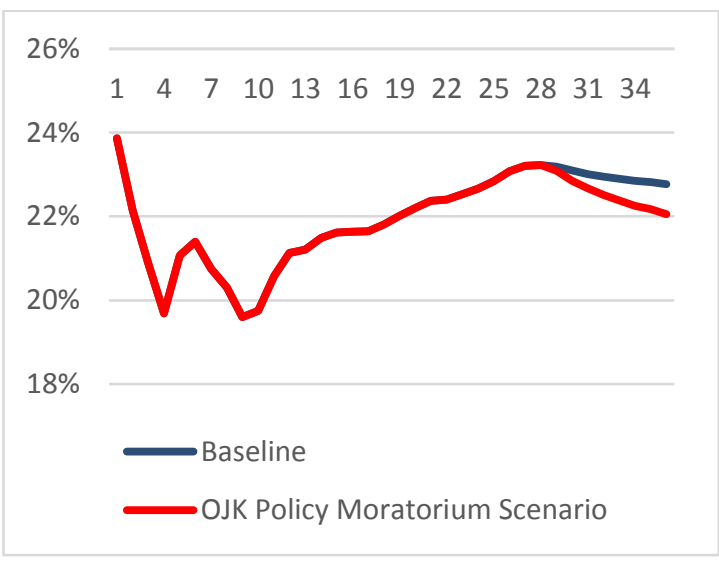

\subsection{Simulation of Bank's Internal Policy for Risk Mitigation}

There is a potential increase in credit and capital risk in case the COVID-19 pandemic prolongs after the OJK restructuring policy is revoked. These risks could be mitigated by simulating and selecting the most effective policy to reduce NPL and increase CAR. The mitigation policy includes the implementation of the NPL monitoring program, management of operational cost and loan interest and deposit rates, and policy combination (policy mix) [43], [23]. The simulated policies are shown in Table 3.

Table 3: Policy Definition to Mitigate Credit and Capital Risk

\begin{tabular}{|l|l|l|}
\hline \multicolumn{1}{|c|}{ Policy } & \multicolumn{1}{|c|}{ Definition } & \multicolumn{1}{|c|}{ Parameter changes in model } \\
\hline 1) NPL Monitoring Program & $\begin{array}{l}\text { A program to monitor the loan } \\
\text { restructuring performance of the } \\
\text { borrowers unable to fulfill } \\
\text { obligations but still have the } \\
\text { capacity to repay the credit and } \\
\text { are considered cooperative. }\end{array}$ & $\begin{array}{l}\text { The initially assumed 50\% of the } \\
\text { loan restructured to become NPLs } \\
\text { is reduced to 10\%. }\end{array}$ \\
\hline $\begin{array}{l}\text { 2) Interest Rate Management } \\
\text { Management }\end{array}$ & $\begin{array}{l}\text { Policies to increase loan interest } \\
\text { and lower deposit interest. }\end{array}$ & $\begin{array}{l}\text { Increasing the loan interest rate } \\
\text { from 7,9\% to 9,5\% annually and } \\
\text { lowering the deposit rate from } \\
1,68 \% \text { to 1,2\% annually. }\end{array}$ \\
\hline $\begin{array}{l}\text { 3) Combination Policies } \\
\text { (Policy Mix) }\end{array}$ & $\begin{array}{l}\text { Policies to reduce bank operating } \\
\text { expenses on salaries, office } \\
\text { utilities, and marketing. }\end{array}$ & $\begin{array}{l}\text { The bank operating cost to income } \\
\text { ratio to be reduced from 39\% to } \\
\text { 32\%. }\end{array}$ \\
\hline
\end{tabular}


The results of the bank internal policy simulation to mitigate risk are presented in Figure 14. A policy could be implemented to bring NPL closer to the baseline ratio to reduce credit risk. The NPL Monitoring Program is the most effective policy to reduce the NPL ratio from $11.89 \%$ to $4.56 \%$. The program involves providing additional new credit facilities, extending terms, and reducing loan interest rates. Consequently, borrowers are enabled to continue their business and pay the credit in installments. The NPL Monitoring Program should be implemented in the economic sectors that survived the pandemic, such as pharmaceutical, telecommunications, social services, and agricultural industries.

Policies 2 and 3 are the operational options that indirectly affect the NPL ratio. In this case, policy 2 is accomplished by bank to increase net interest income, while 3 reduces the operational expenses. Policy 4 is a mix that results in a reduced NPL Ratio similar to 1.

The simulation of the four policies on changes in capital risk due to the OJK credit moratorium resulted in different patterns as shown in Figure 15. The order of policies that increase the CAR from the highest is 4, followed by 2, 1 , and 3 . Policies 4 and 2 increased CAR to $23.38 \%$ and $22.99 \%$ above the baseline level, respectively. Policies 1 and 3 increased CAR beyond the OJK Policy Moratorium of $22.57 \%$ and $22,42 \%$, respectively, but still below the baseline level.

Policy 4 is a combination policy that increases capital significantly compared to other policies. The source of additional capital is the net interest income from policies 1 and 2 and cost efficiency from policy 3. The additional capital as the result of policy 4 proportionally increases the CAR ratio.

Figure 14: Comparison Policy Scenarios to Credit Risk (NPL Ratio)

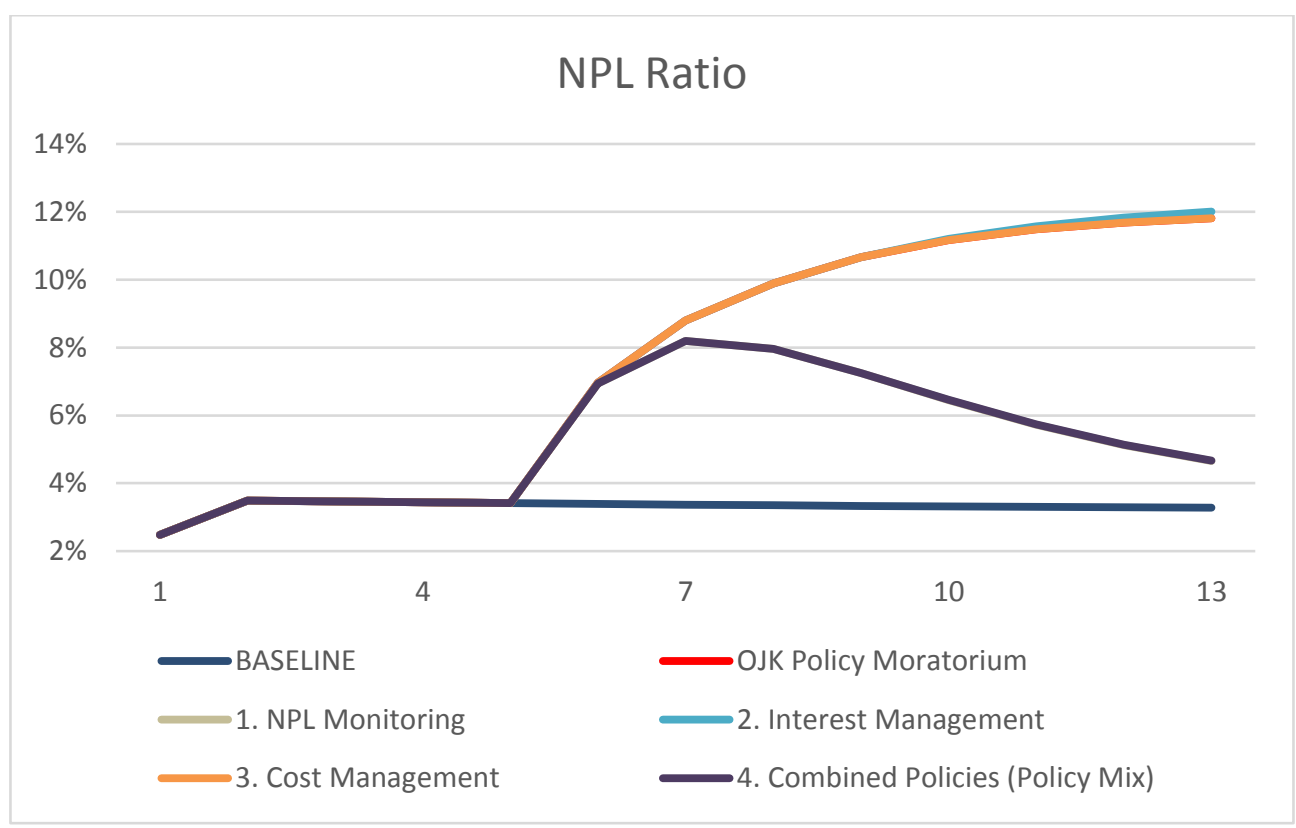


Figure 15: Comparison Policy Scenarios to Capital Risk (CAR)

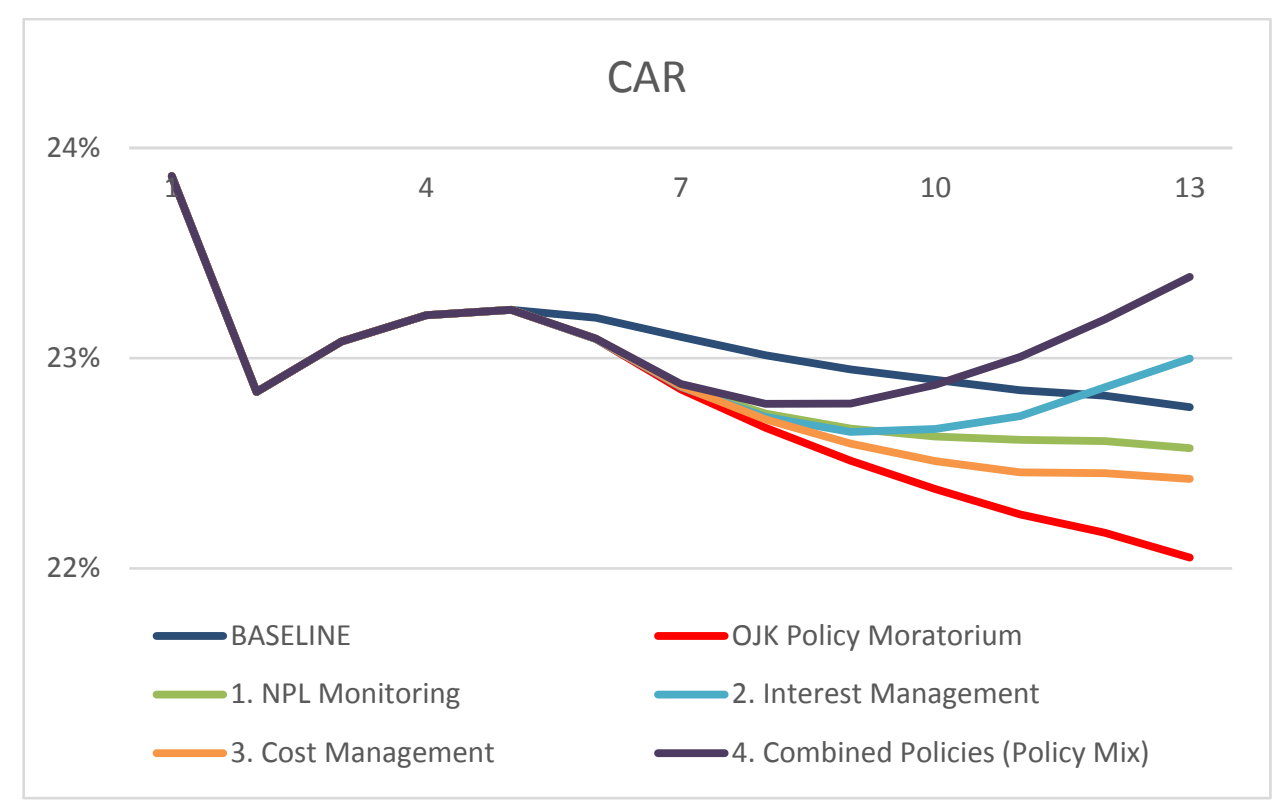

\subsection{Discussion}

The current global pandemic has affected many aspects of human life. This has prompted studies on the impact of the COVID-19 pandemic in economic sectors including the banking sector as well as in other sectors such as in the higher education institutions and mental health [24], [48]. This study examines several bank efforts to maintain credit risk (NPL) and bank capital adequacy (CAR) during the pandemic.

The simulation result of the OJK credit restructuring policy moratorium shows that the COVID-19 pandemic caused an increase in NPLs. This is similar to some previous studies in Indonesia, Bangladesh and Poland, in which confirmed that there was an increase in NPL during the COVID-19 pandemic [18], [19], [11], [26]. The increase in banks' NPL could be mitigated through various ways, such as NPL monitoring activity [23], [43]. This study confirmed that the NPL Monitoring Program could significantly reduce the NPL ratio.

An increase in NPLs causes a decrease in CAR [35]. However, this study shows the increase in NPL is not always proportional to the decrease in CAR, provided the bank still has an adequate allowance for impairment losses. Based on the simulation test on credit and bank operation, each policy produces different impact. The bank operational policies such as the interest rate and operating cost management program could improve the level of CAR.

The changes in NPL or the increase of credit risk affect the bank's ability to generate profits as additional capital [15]. Furthermore, the COVID-19 pandemic affected Indonesian banks' profit and capital performance [35], [18]. The simulation at BNI Bank shows that the increase in NPL ratio reduces the CAR level, a problem to be overcome through a policy scenario. According to the theory of bank management, the effective policy options to maintain CAR and monitor NPLs ratio include interest rate and operating cost management program [23]. The policy simulations at BNI Bank show that CAR could be maintained by implementing a mixed policy.

\section{Conclusion}

The purpose of the study is to provide the bank risk scenario after the credit restructuring policy of the OJK moratorium in March 2022 and the internal bank policy alternatives to mitigate credit and capital risks in terms of Non-Performing Loan (NPL) and Capital 
Adequacy Ratio (CAR). For this purpose, the study develops a system dynamic-based simulation model for BNI Bank, an Indonesian state-owned bank that impacted the COVID-19 pandemic. The result demonstrates that the NPL increases as the effect of the pandemic and it reduces the level of CAR. Regarding the bank internal policy scenario, the simulation proposes 4 policies, in which the best policy is the recommendation that BNI Bank can implement the NPL Monitoring Program to reduce the NPL ratio as well as the interest rate and operating cost management program to maintain the level of CAR.

The contribution of this study compare to the previous studies is that this study develops the new model of risk scenario and policy simulation while the COVID-19 pandemic is still ongoing and the economy is not yet normal. While other studies only calculated the impact and the level of credit risk (NPL) that have happened. The advantage of this study is that the model could be tested and implemented to other banks as far as the bank's financial reports are available.

\section{References:}

[1] Adamides, E.D., 2008. System Dynamics Modelling in The Development of Management and Organisational Theory. The 26th International Conference of the System Dynamics Society. The System Dynamics Society.

[2] Adrian, Tobias and Narain, Aditya. 2020. Maintaining Banking System Safety amid the COVID-19 Crisis. https://blogs.imf.org/2020/03/31/maintain ing-banking-system-safety-amid-the-COVID-19-crisis.

[3] Akkermans, H. A. and Oorschot, K. E. van. 2005. A Case Study of Balanced Scorecard Development Using System Dynamics. The Journal of the Operational Research Society, Vol. 56, No. 8 (Aug. 2005), pp. 931-941.

[4] Anderson, S., Long, C., Jansen, C., Affeldt, F., Rust, J. and Seas, B. 2011. Banking Dynamically Stress Testing
Financial Systems. Proceedings of the 29th International Conference of the System Dynamics Society, Washington, DC.

[5] Altman, E. 1977. Predicting Performance in The Savings and Loan Association Industry. Journal of Monetary Economics, 3 (1977) 443-466.

[6] Alwani, Mazen Jamil. 1980. The Management of a Commercial Bank's Funds: A System Dynamics Study. Ph.D. Dissertation at The University of Bradford United Kingdom.

[7] Atkinson, T., Luttrell, D. and Rosenblum, H., 2013. How bad was it? The costs and consequences of the 2007-09 financial crisis. IMF Staff Papers, (Jul 2013).

[8] Baker, S. R., Bloom, N., Davis, S. J., and Terry, S. J. 2020. COVID-Induced Economic Uncertainty (Working Paper No. 26983; Working Paper Series, National Bureau of Economic Research. https://doi.org/10.3386/ w26983.

[9] Bank Indonesia. 2021. Kajian Stabilitas Keuangan. No. 36. Maret 2021.

[10] Barlas, Yaman. 2002. System Dynamics: Systemic Feedback Modeling for Policy Analysis. System Dynamics - Vol. I.

[11] Barua, B. and S. Barua. 2021. COVID-19 Implications for Banks: Evidence from an Emerging Economy. SN Business \& Economics, 1: 19. Springer

[12] Beaver, W. 1966. Financial ratios as predictors of failure. Journal of Accounting Research, 5: 71-111.

[13] Beran, Ivona Milić. 2015. System Dynamics Modelling and Simulating the Effects of Intellectual Capital on Economic Growth. Croatian Operational Research Review, CRORR 6 (2015), 445457.

[14] Bouvatier, V., Brei, M., and Yang, X. 2013. The determinants of bank failures in the United States: Revisited. Gdre2013.conference.univ-poitiers.fr.

[15] Cole, Rebel A., and White. Lawrence J. 2012. Déjà Vu All Over Again: The Causes of U.S. Commercial Bank Failures 
This Time Around. Journal of Finance Service Res, 2012, 42:5-29

[16] Estrella Arturo., Park, Sangkyun. and Peristiani, Stavros. 2000. Capital Ratios as Predictors of Bank Failure. FRBNY Economic Policy Review/July 2000.

[17] García, Juan Martín. 2019. Common Mistakes in System Dynamics. Reviewer John Lamy ISBN: 9781791578787, jmg@atc-innova.com.

[18] Hardiyanti, Siti Epa dan Lukmanul Hakim Aziz. 2021. The Case of COVID-19 Impact on the Level of Non-Performing Loans of Conventional Commercial Banks in Indonesia. Banks and Bank Systems, 16(1), 62-68. doi:10.21511/ bbs.16 (1).2021.06.

[19] Hasan, I., P Politsidis, Z Sharma. 2020. Bank Lending During the COVID-19 Pandemic. MPRA Paper No. 103565, posted 21 October 2020 15:42 UTC. Mpra.ub.uni-muenchen.de.

[20] Islam, T., Vasilopoulos, C., and Pruyt, E. 2013. Stress-testing banks under deep uncertainty. In Proceedings of the 31st International Conference of the System Dynamics Society, Cambridge, Massachusetts, USA, 21-25 July 2013.

[21] Istiaq, Muhammad. 2015. Risk Management in Banks: Determination of Practices and Relationship with Performance. Ph.D Dissertation the University of Bedfordshire.

[22] Kasinger, J., Krahnen, JP., Ongena, and Pelizzon. 2021. Non-performing loans new risks and policies? NPL resolution after COVID-19: Main differences from previous crises. SAFE White Paper, No. 84, Leibniz Institute for Financial Research SAFE, Frankfurt.

[23] Koci, Donart., Morina, Festina., Hoxhaj, Fatlinda., Ukëhaxhaj, Antigona. 2021. The Impact of COVID-19 on Mental Health. International Journal of Biology and Biomedical Engineering, Volume 15, pp. 202-211.

[24] Koch, Timothy., MacDonald. Scott., Edwards, Vic., and Duran, Rendall E.
2014. Bank Management 8th edition. Concage Learning. Boston.

[25] Korzeb, Z., and Niedziółka, P. 2020. Resistance of commercial banks to the crisis caused by the COVID-19 pandemic: the case of Poland. Equilibrium. Quarterly Journal of Economics and Economic Policy, 15(2), 205-234. doi: 10.24136/eq.2020.010.

[26] Kulińska-Sadłocha, E. \& M Marcinkowska. 2020. The Impact of Pandemic Risk on the Activity of Banks Based on the Polish Banking Sector in the Face of COVID-19. Safe Bank, 2(79) 2020.

[27] Maani, K .2011. System Dynamics and Organizational Learning; Complex Systems in Finance and Econometrics, in RA Meyers (ed.), Springer New York, pp. 738-52.

[28] MacDonald, R. H., and Dowling, Anne M. 1993. The Savings and Loan Crisis: system dynamics Perspective. Proceedings of the 11th International Conference of the System Dynamics Society. Cancun, Mexico.

[29] Martin, D., 1977. Early Warning of Bank Failure: A Logit Regression Approach, Journal of Banking and Finance, Nov. 1977, vol. 1, pp. 249 - 276.

[30] Mayes, David G. and Stremmel, Hanno, 2012. The Effectiveness of Capital Adequacy Measures in Predicting Bank Distress. Financial Markets \& Corporate Governance Conference. Available at SSRN: https://ssrn.com/abstract2191861.

[31] Meyer, P.A., and Pifer, H.W., 1970. Prediction of bank failures. The Journal of Finance, 25(4), pp.853-868.

[32] Munir, Q, and Kok, SC. 2016. Early Warning System for Banking Crisis: Causes and Impacts. Handbook of Research on Financial and Banking. IGI Global.

[33] Pruyt, Erik. 2010. Using Small Models for Big Issues: Exploratory System Dynamics Modelling and Analysis for Insightful Crisis Management. 28th International Conference of the System Dynamics Society, Seoul, Korea, 25-29 July 2010. 
[34] Pruyt, E. and. Hamarat, C. 2010. The Concerted Run on the DSB Bank: An Exploratory System Dynamics Approach. Proceedings of the 28th International Conference of the System Dynamics Society, Seoul, Korea, 25-29 July 2010.

[35] Rahmi, Yulia., dan Sumirat, Erman. 2021. A Study of The Impact of Alma to Profitability During the Covid-19 Pandemic. International Journal of Business, Economics and Law, Vol. 24, Issue 3 (April). ISSN 2289-1552 2021. 54.

[36] Reynolds, M. \& Holwell, S. 2020. Systems Approaches to Making Change: A Practical Guide. Springer.

[37] Rose, P. 1992. Agency Theory and Entry Barriers in Banking. The Financial Review, 27(3), 323 - 354.

[38] Sapiri, Hasimah., Jafri Zulkepli., Norazura Ahmad., Norhaslinda Zainal Abidin., dan Nurul Nazihah Hawari. 2020. Introduction to System Dynamics Modelling and Vensim Software. UUM Press.

[39] Sinkey, J.F., 1975. A multivariate statistical analysis of the characteristics of problem banks. The Journal of Finance, 30(1), pp.21-36.

[40] Sterman, John D. 1983. Appropriate Summary Statistics for Evaluating the Historical Fit of System Dynamics Models. Sloan School of Management. Massachusetts Institute of Technology. Cambridge.

[41] Sterman, J. D. 2000. Business Dynamics: Systems Thinking and Modeling for a Complex World. Boston, McGraw-Hill.

[42] Sun, J., Li, H., Huang, QH., and He, KY. 2014. Predicting financial distress and corporate failure: A review from the stateof-the-art definitions, modeling, sampling, and featuring approaches. KnowledgeBased Systems, 57, pp $41-56$.

[43] Sutaryono, Paul. 2020. Mengawal Restrukturisasi Kredit? Inilah Kiat-nya!. https://infobank-news.com/analisis/mengawal-restrukturisasi-kredit-inilahkiatnyal.
[44] Sy, C., Bernardo, E., Miguel, A., San Juan, J. L., Mayol, A. P., Ching, P. M., Culaba, A., Ubando, A., and Mutuc, J. E. 2020. Policy Development for Pandemic Response Using System Dynamics: a Case Study on COVID-19. Process Integration and Optimization for Sustainability, 1-5. Advance online publication. https://doi.org/10.1007/s41660-02000130-x.

[45] Trendowski, Joseph. 2012. A Study of Failures in The US Banking Industry. A Dissertation Submitted to the Faculty of Old Dominion University.

[46] Uriona, Maldonado Mauricio., dan Sara, Grobbelaar. 2017. System Dynamics Modelling in The Innovation Systems Literature. Paper presented at the 15th Globelics International Conference, Athens, Greece, October 11-13.

[47] Wu, Xiaoyu and Zhao, Leon. 2012. Systemic Decision Making for Liquidity Risk Management in Banks (29 July 2012). AMCIS 2012 Proceedings. Paper 35.

[48] Zulkri, Muhammad Farezuan., Shaharudin, Shazlyn Milleana., Rajak, Noor Azrin Abdul., Ibrahim, Muhammad Safwan. 2021. Predictive Analytics on Academic Performance in Higher Education Institution during COVID-19 using Regression Model. International Journal of Biology and Biomedical Engineering, Volume 15, pp. 184-189.

\section{Contribution of individual authors to the creation of this scientific article:}

Taufiq Hidayat carried out the conception and design of the work, drafting the article. Dian Masyita reviewed the works of literature and approved the version to be published.

Sulaeman Rahman Nidar reviewed data analysis and interpretation.

Erie Febrian worked on the critical revision of the paper.

Fauzan Ahmad worked on data collection, modeling, and simulation. 
The research presented in this scientific article was self-funded.

Correspondent

author:

taufiq.hidayat@ibs.ac.id
Creative Commons Attribution License 4.0 (Attribution 4.0 International, CC BY 4.0)

This article is published under the terms of the Creative Commons Attribution License 4.0

https://creativecommons.org/licenses/by/4.0/de ed.en US 


\section{Appendix. Initial Values and Constant Values of the Baseline Model}

\begin{tabular}{|c|c|c|c|}
\hline Name & Unit & Initial Values & Variable Type \\
\hline Equity & Million IDR & $116,898,206$ & level \\
\hline Liquid Asset & Million IDR & $105,336,365$ & level \\
\hline Marketable Securities & Million IDR & $108,828,780$ & level \\
\hline National loan market 2020 & Million IDR & $8,280,811,798$ & level \\
\hline Non-performing loan NPL & Million IDR & $12,172,350$ & level \\
\hline Performing loan & Million IDR & $507,181,260$ & level \\
\hline Restructured Loan & Million IDR & - & level \\
\hline Third-party fund TPF & Million IDR & $582,966,966$ & level \\
\hline Adjust time end & Month & 6 & constant \\
\hline Adjust time-end credit & Month & 60 & constant \\
\hline Adjust time start & Month & 1 & constant \\
\hline Adjust time start for credit & Month & 3.5 & constant \\
\hline Adjustment delay impairment rate & Month & 3 & constant \\
\hline Capital Adequacy Ratio Standard & $\%$ & $10 \%$ & constant \\
\hline Converter month to a year & Month/Year & 12 & constant \\
\hline COVID time & Month & 3.07 & constant \\
\hline Credit Risk Factor in Pandemic & $\%$ & $80 \%$ & constant \\
\hline Delay time paid NPL Write off & Month & 24 & constant \\
\hline Duration & Month & 12 & constant \\
\hline Loan maturity & Per month & $0.20 \%$ & constant \\
\hline NPL 2020 & $\%$ & $2.90 \%$ & constant \\
\hline NPL Ratio Target 2021 & $\%$ & $4.50 \%$ & constant \\
\hline NPL Write off rate & Per month & $2.40 \%$ & constant \\
\hline Payment Fraction of Write of Loan & $\%$ & $20.00 \%$ & constant \\
\hline Realized NPL rate & Per month & $0.22 \%$ & constant \\
\hline Response time to credit & Month & 1 & constant \\
\hline Rest Loan Fraction to NPL & $\%$ & 0 & constant \\
\hline Target loan impairment rate & Per month & 0.0055 & constant \\
\hline Target NPL restructuring & Per month & 0.0025 & constant \\
\hline Time to the average loan market & Month & 12 & constant \\
\hline Time to correct performing loan & Month & 1 & constant \\
\hline Time to distribute additional loan & Month & 1 & constant \\
\hline Time to outflow restructured loan & Month & 1 & constant \\
\hline Time to restructuring & Month & 2 & constant \\
\hline Transition time rest loan to NPL & Month & 2 & constant \\
\hline Profit and loss period & Month & 1 & constant \\
\hline BNI market share & $\%$ & $13.00 \%$ & Graph \\
\hline Loan market growth & Per month & $0.20 \%$ & Graph \\
\hline Loan market growth & Per year & $2.40 \%$ & Graph \\
\hline Target loan market share assumption & $\%$ & $6.20 \%$ & Graph \\
\hline Interest rate TPF & Per year & $2.79 \%$ & Graph \\
\hline
\end{tabular}

